\title{
THE EFFECT OF OREXIN A APPLICATION ON THE REACTION OF MICROGLIA CELLS BODY SIZE STIMULATED BY LPS INJECTION
}

\author{
A.P. Synchikova ${ }^{1,2}$, H. Horiuchi ${ }^{1}$, J. Nabekura ${ }^{1}$ \\ ${ }^{1}$ National Institute for Physiological Sciences, Okazaki, Japan; \\ ${ }^{2}$ Institute of Experimental Medicine, Saint Petersburg, Russia
}

\section{ЭФФЕКТ ВВЕДЕНИЯ ОРЕКСИНА А НА ИЗМЕНЕНИЕ РАЗМЕРОВ КЛЕТОЧНОГО ТЕЛА КЛЕТОК МИКРОГЛИИ, СТИМУЛИРОВАННЫХ ВВЕДЕНИЕМ ЛПС}

\author{
А.П. Сынчикова ${ }^{1,2}$, Х. Хориучи ${ }^{1}$, Ю. Набекура ${ }^{1}$ \\ ${ }^{1}$ Национальный институт физиологических наук, Оказаки, Япония; \\ ${ }^{2}$ ФГБНУ «Институт экспериментальной медицины», Санкт-Петербург
}

The purpose of this study is to determine the effect of orexin A to LPS-activated microglia by investigating the morphological change. The effect of orexin on the level of LPS-activated microglia activation during the transition to the M1 phenotype was determined, which can be studied by measuring the cell area of the body.

Keywords: microglia; orexin A; cell body of microglia.

Целью данного исследования является определение влияния орексина А на клетки микроглии, активированные инъекцией ЛПС, путем изучения морфологических изменений. Определялось влияние орексина на уровень активации ЛПС-активированной микроглии при переходе к фенотипу М1, что можно изучить, измеряя площадь клетки тела.

Ключевые слова: микроглия; орексин А; клеточное тело микроглии.

Introduction. The purpose of this study is to determine the effect of orexin A to LPS-activated microglia by investigating the morphological change.

Microglia are initiators of the neuroinflammatory response and are highly reactive to endogenous signaling. Microglia are highly dynamic, transitioning between neurotoxic pro-inflammatory (M1) and neuroprotective (M2) phenotypes. For example, following cerebral ischemic events, microglia are first activated to a neuroprotective M2 phenotype as oxygen levels decrease, and then switch to a pro-inflammatory M1 phenotype, inducing cell death [1].

The goal of this study was to determine the effect of orexin on the level of activation of LPS-activated microglia by transition to phenotype M1, what possible noticed by changing the area cell body.

The neuropeptide Orexin A is formed from the precursor protein preprorexin (131 amino acids). It has a 33-amino acid $\mathrm{N}$-terminal signal sequence. Axons of the orexin-producing cells of the hypothalamus project throughout all parts of the brain and affect functions of various systems.

Orexin receptors are found on the membrane of microglial cells.

Orexin (hypocretin) as a neuropeptide involved in the control of feeding behavior, arousal or sleep behavior [2].

Orexin $\mathrm{A}$ has a neuroprotective effect in the brain. In the cerebral cortex, orexin A can also help reduce inflammation and neurodegeneration through microglia-mediated pathway [3].

The cells death of hypothalamic neurons exposed to conditioned media from microglia after treatment with palmitic acid was reduced if microglia cells were preincubated in culture with the addition of orexin A. These data support that orexin A can act as a regulator of microglial function, as shown under the effect of orexin the release of proinflammatory cytokines by microglial cells and the intensity of the inflammatory process are reduced. However, it is known that proinflammatory stimuli, such as LPS, increase the expression of orexin A receptors on microglial cells [4]. Also shown that astrocytes respond to OxA, which binds to receptors on their membrane through Ox1R and stimulates the migration of these cells after application of orexin A, which indicates the effect of orexin A on astrocyte activity [5].

With the injections of LPS, wild-type and knockout mice that did not have orexin-containing neurons in the hypothalamus showed significant differences in intensity of recovery from the inflammatory process. Orexin expression was suppressed after injection of LPS in wild-type mice and was completely absent in knockout animals.

Decreased production of orexin affects the expression of hypothalamic inflammatory factors in response to LPS, such as gamma-interferon and a colony stimulating factor. 
In this paper, we investigated the effects of Orexin A on the size of microglial cells stimulated by the introduction of LPS, since it is known that an increase in their size indicates the degree of activity of these cells.

Materials and methods. Experimental Animals (refer Akiyoshi 2018 eNeuro). Wild type mice (c57BL6, male, age 2 months) were injected into the second ventricle of the brain with $1 \mu \mathrm{l}$ of orexin-A solution (Sigma-Aldrich, USA) at a concentration of $0.3 \mathrm{mM}(n=9) \mathrm{c}$, and saline (0,9 PBS) in the same volume of $1 \mu \mathrm{l}(n=8)$ was administered as a control. One hour after the injection, lipopolysaccharide (Funakoshi chemical, Tokyo, Japan) was injected intraperitoneally at a dose of $2 \mathrm{mg} / \mathrm{kg}$ to animals of both groups. 7 hours after the start of the experiment, the animals were perfused, and the brains were removed for further fixation and immunohistochemical analysis.

Immunohistochemistry. To quantify microglia morphology, mice were transcordially perfused with $4 \%$ paraformaldehyde in phosphate buffer (PB, pH7.4) and overnight fixation with same fixative solution. Fixed brains were cut with a microtome (Leica Microsystem, Germany) into $50 \mu \mathrm{m}$ thick sections.

Primary monoclonal rabbit antibodies to Ibal (1: 500, Wako, Osaka, Japan) were used in this work. Brain sections were incubated overnight with primary antibody, washed with phosphate buffer, and incubated with secondary antibodies conjugated with a fluorescent label (Alexa Flour 488, Abcam, United Kingdom). The preparations were washed with phosphate buffer and mounted on glass slides. The cell nuclei were stained with VEC H-1200 fluorescent dye with DAPI. For verification of microglial cells in the brain tissue was used by visualization on a confocal laser scanning microscope Nicon Eclipse TI (Tokyo, Japan)

Morphological analysis. The sizes of the bodies of microglial cells in the somatosensory and motor zones of the cortex were studied (Fig. 1).

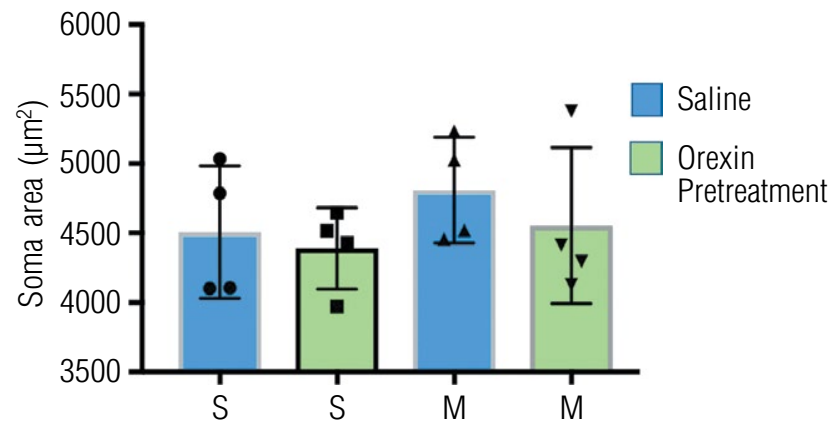

Fig. 1

In this experimental design, a change of cell body of microglial cells stimulated with LPS with the introduction of orexin does not occur.

Future analysis of the complete profile of proand anti-inflammatory cytokines could provide insight into how priming microglia with OxA can provide a favorable brain microenvironment for neurons. One of the mechanisms of this phenomenon is a transition of microglial cells to the M2 phenotype (activated, capable of phagocytosis) or, at least, slowing down the transformation of these cells into the M1 state (inactive state). In studies of acute neuro-inflammatory reactions, microglial cells were transformed to the protective M2 phenotype (including an increase in arginase-1 expression), which resulted in a decrease in neuronal damage and intensity of inflammation [2]. These data suggest that orexin affects the activation of microglial cells, reducing the pro-inflammatory release of cytokines, which increases the neuron survival.

It is known that an informative indicator of the change in the activity degree of microglial cells is the ratio of the size of the cell body and the duration of processes, and these changes are currently being analyzed.

Acknowledges. This study was supported by Japan-Russian Youth Exchange Center (JREX, Tokyo, Japan).

\section{References}

1. Hu X, Li P., Guo Y, et al. Microglia/macrophage polarization dynamics reveal novel mechanism of injury expansion after focal cerebral ischemia. Stroke. 2012;43(11):3063-70.

2. Willie JT, Chemelli RM, Sinton CM, Yanagisawa M. To eat or to sleep? Orexin in the regulation on feeding and wakefulness. Annu Rev Neurosci. 2001;24:429-458.

3. Xiong $\mathrm{X}$, White RE, $\mathrm{Xu} \mathrm{L}$, et al. Mitigation of murine focal cerebral ischemia by the hypocretin/orexin system is associated with reduced inflammation. Stroke. 2013;44(3):764-70.

4. Duffy CM, Yuan C, Wisdorf LE, et al. Role of orexin A signaling in dietary palmitic acid-activated microglial cells. Neurosci Lett. 2015;606:140-4.

5. Shu Q, Hu Z-L, Huang C, et al. Orexin-A Promotes Cell Migration in Cultured Rat Astrocytes via $\mathrm{Ca}^{2+}$-Dependent PKC $\alpha$ and ERK1/2 Signals. PLoS One. 2014 Apr 18;9(4). https://doi.org/10.1371/journal. pone.0095259. 